\title{
Oxygen Gives Life; Oxygen Takes Away Life
}

\author{
B. Saha ${ }^{1, *}$, J. Miller ${ }^{2}$ \\ ${ }^{1}$ Former lecturer, NESCOT College, EPSOM, Surrey, UK \\ ${ }^{2}$ GP, Glenlyn Medical Center, East Molesey, Surrey, UK \\ *Corresponding author: bensaha19@yahoo.com
}

\begin{abstract}
This article highlights the fact that Oxygen is the protector of human life but can also act to cause its destruction through chemical reactions that take place within the body as we breathe in oxygen. The article suggests a means of alleviating the deadly diseases that may result from these chemical reactions - the production of oxygen free radicals within the body. Timely use of appropriate antioxidant foods is advised in order to neutralize the detrimental effects of these oxygen free radicals.
\end{abstract}

Keywords: Oxygen $\left(\mathrm{O}_{2}\right)$, carbon dioxide $\left(\mathrm{CO}_{2}\right)$, oxygen free radical, body's DNA, cancerous cells, electron, antioxidant food, longevity

Cite This Article: B. Saha, and J. Miller, “Oxygen Gives Life; Oxygen Takes Away Life.” American Journal of Food and Nutrition, vol. 6, no. 1 (2018): 14-16. doi: 10.12691/ajfn-6-1-3.

\section{Introduction}

Human being cannot sustain life without oxygen $\left(\mathrm{O}_{2}\right)$. It is so obvious in our day to day living that we breathe in oxygen which maintains our body system, enabling our body to function properly. Thus our life is sustained. Then, of course, we breathe out carbon dioxide $\left(\mathrm{CO}_{2}\right)$. Refer to the following picture, Figure 1, as an example [1].

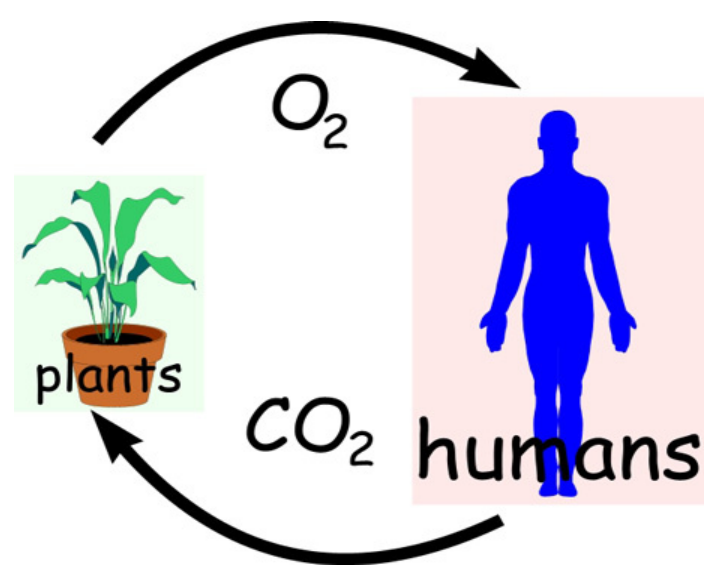

Figure 1. A picture of $\mathrm{O}_{2} / \mathrm{CO}_{2}$ recycles

Human body is made up of about 37.2 trillion cells [2]. As we breathe in and out, chemical reactions take place within our body at the molecular level. Some oxygen molecules, under certain circumstances, will degenerate and harm the body.

The analogy of this chemical reaction of oxygen is like a burning candle, see the picture below [3], Figure 2. The candle is giving light, but it is leaving behind some black soot - carbon molecules. Likewise, we breathe out carbon dioxide, but traces of them are left inside our body. Of course, our body's defensive system endeavours to purify these impurities.

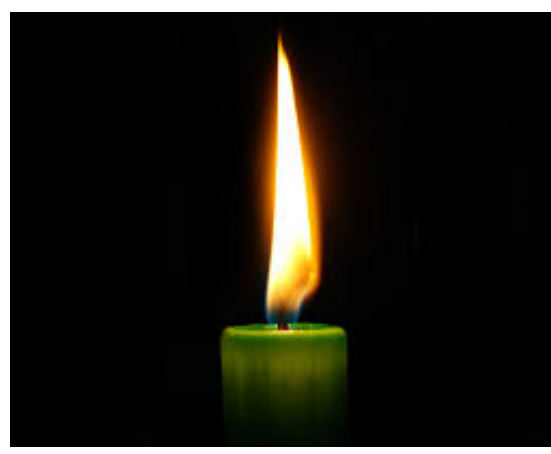

Figure 2. A candle is burning

Thus, two formidable forces are in constant combat within our body, destructive oxygen molecules - oxidants, and the body's police force, known as antioxidants. The latter comes forward to protect our body against the destructive power of renegade oxidants. Although some oxidants are beneficial, providing us energy to move on and some are routinely generated during normal metabolic process inside our body, many of these oxidants are, however, malevolent invaders. These are called "oxygen free radicals" or simply "free radicals" [4].

\section{Main Sources of "Oxygen Free Radicals"}

The main sources may be attributed to the following areas:

- Waste products of ordinary metabolic process, such as breathing and body's immune reactions

- Air pollutants, e.g. arising from car exhaust, that get inside our lungs as we breath in

- Toxic industrial chemicals, pesticides as we breathe air in (See the following picture below [5], Figure 3, as an example) 
- Cigarette smoke and drugs, as we smoke and someone takes drug (See the following picture below [6], Figure 4, as an example)

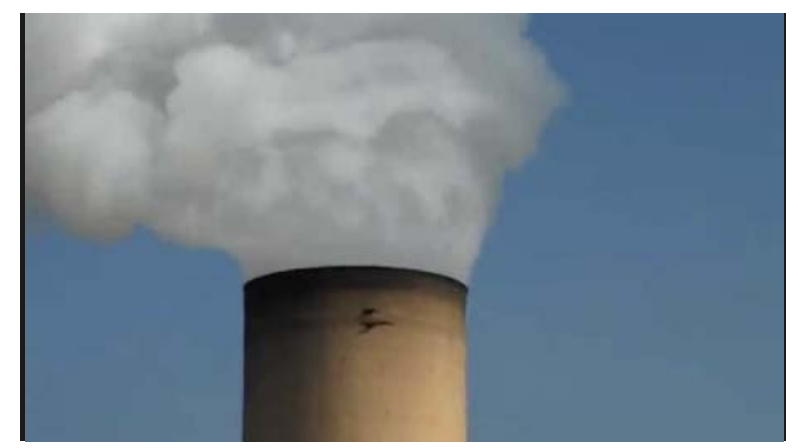

Figure 3. Picture of a chimney emitting smoke and $\mathrm{CO}_{2}$

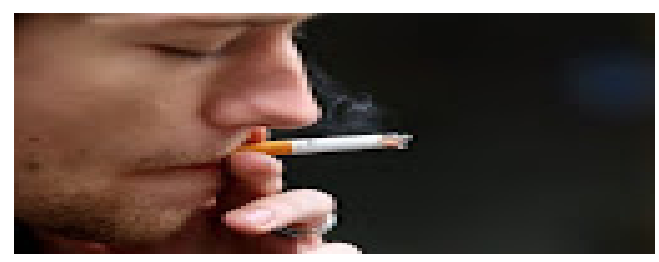

Figure 4. A person gaily smoking

\section{Destructive Power of Oxygen Free Radicals [4]}

As referred to above, oxidants come in various forms and guises. The most notorious and well known forms are called oxygen free radicals. By their very chemical structure these molecules are positively charged up. At the atomic level, they have lost one electron. Absence of this electron has made them chemically unstable. In order to be stable they need one additional electron in their shell structure. In their frantic search for another electron, they will try to grab it from anywhere within the body. Thus they attack healthy cells in the body, destroying them in their path, and creating more gangs of more free radicals in split seconds that become out-of-control chain reactions (See the following picture of electrons orbiting the nucleus [7], Figure 5, as an example)

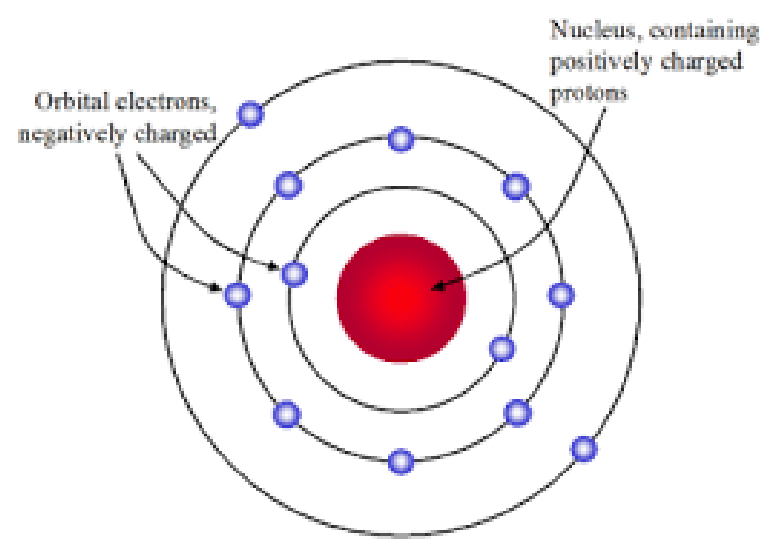

Figure 5. In case of an oxygen free radical, one electron is lost from the outer shell and the molecular structure become hungry to grab an electron from anywhere in the body cell for stability
The net result is that the oxygen free radicals can attack body's DNA, the genetic materials of cells, causing them to mutate, which is a first step on the path to cancer. Even more awesome - free radicals attack the fatty parts of cell membranes. The fatty parts are, in fact, anti-oxidants work in the opposite manner of oxidants, protecting the cell. Left defenceless without enough antioxidants, these fatty molecular cells become peroxidised, in another word, they become rancid. This process can completely disrupt the cell membrane's structure. Worse, each peroxidised fat molecule is now like a torch, capable of peroxidising any new fatty molecule it comes in contact in the body fomenting a chain reaction. This will continue until it is interrupted or exhausted.

One can now envision destructive oxidants as wanton molecular gangs that roam our body, mugging cells, ripping their membranes, corrupting their genetic materials, turning fat rancid and leaving cells to die. The following pictures, Figure 6 \& Figure 7, show how the cancer starts and how it spreads (shown below as examples. Note: The formation of cancerous cells in the body and how it can be alleviated by food therapy will be the subject of further investigation and research by the authors - the results will be published in a separate article).

\section{(a) How Cancer Starts [8]}
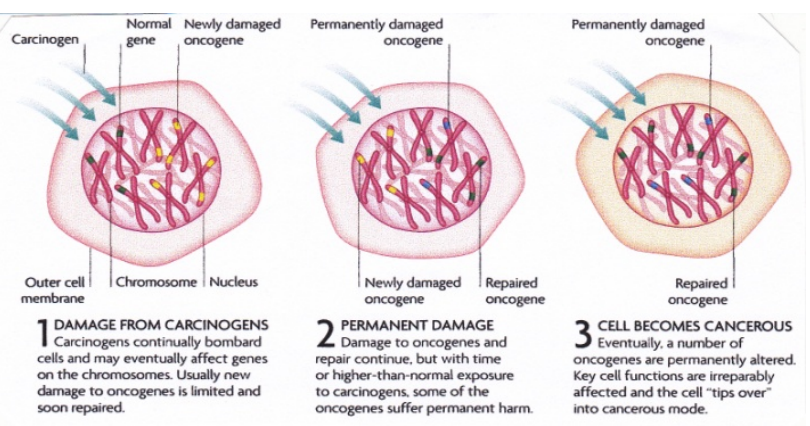

Figure 6. How cancer is initiated in the human body

\section{(b) How Cancer Spreads [8]}

\section{(i) Spread by Lymph}

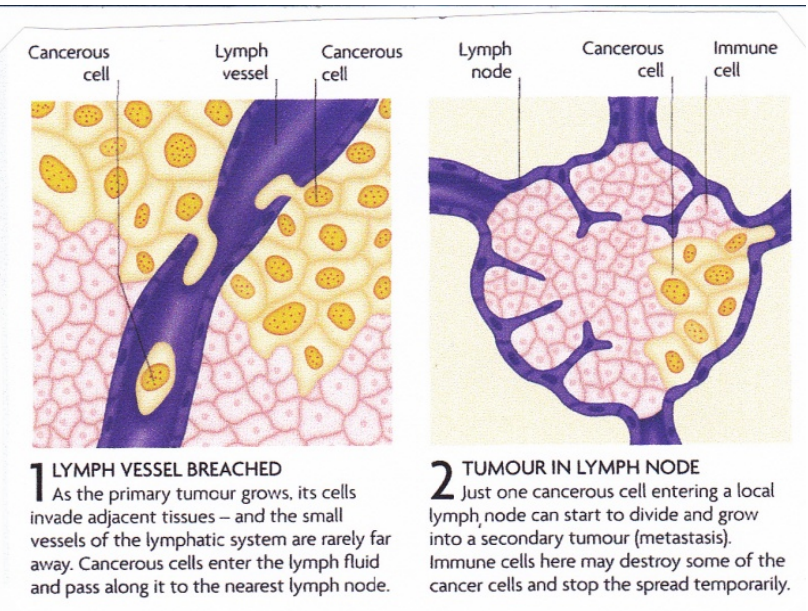

(ii) Spread by Blood 


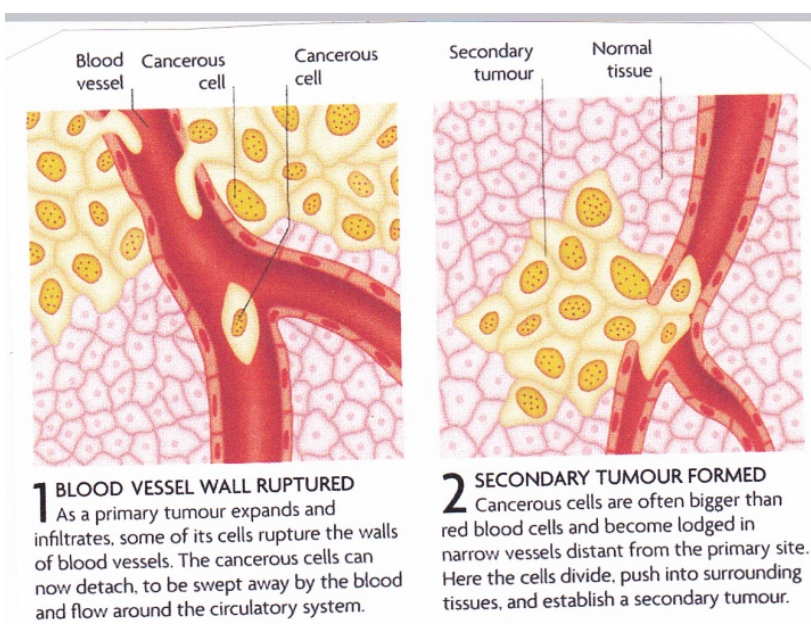

Figure 7. How cancer spreads within the human body

\section{How Oxygen Takes Life Away?}

Breathing in oxygen gives rise to potential detrimental oxidation process within the body that may take place. However, this oxidation process is so gradual and painless, occurring over the years that we do not notice it until the cumulative damage springs out to what we call "symptom of disease" This symptom may include inflammation, deteriorating vision, chest pain, chronic headache, abdominal pain, poor concentration and cancer.

(Note: Damage and destruction of body's cells also occur naturally as people age and their appearance changes).

\section{What is the Answer to Stop/Reduce Such a Destructive Activity of Oxygen?}

The answer lies in strengthening of our body's police force. This comes as antioxidants derived from the food as we eat to survive.

Some major antioxidants in foods are:

1. Beta-carotene (found in dark green leafy vegetables, carrots, apricots)

2. Glutathione (found in avocado, asparagus, water melon)

3. Indoles (found in broccoli, Brussels sprouts, cabbage, cauliflower, kale, mustard, radish)

4. Lycopene (found in tomato, water melon, apricots)

5. Quercetin (found in yellow and red onions, red grapes, broccoli and yellow squash)

6. Ubiquinol 10 (Co- enzyme $\mathrm{Q}_{10}$ ) (found in sardines, mackerel, peanut, pistachio nuts, sesame seeds and some meats)

7. Vitamin $C$ (found in red and green bell peppers, broccoli, Brussels sprouts, cauliflower, spinach, lemon and cabbage)

8. Vitamin E (Tocopherol) (found in vegetable oils, almonds, soya beans, sun flower seeds)

9. Vitamin A (Form 1- retinol: found in liver, eggs, butter, cod liver oil, Form 2: beta-carotene: found in any bright coloured fruits and vegetables, e.g. carrots)
10. Vitamin $B$ series $\left(B_{1}\right.$ : found in whole grains, brown rice, sea food and legumes, $\mathrm{B}_{2}$ : found in milk, liver, kidneys, yeast, cheese, and leafy green vegetables, $B_{3}$ : found in liver, lean meats, whole grains, peanuts, eggs, avocados and fish, $\mathrm{B}_{5}$ : found in whole grains, kidneys, nuts, chicken, molasses and eggs, $\mathrm{B}_{6}$ :found in brewer's yeast, liver, kidneys, heart, melon, cabbage, molasses and eggs, $\mathrm{B}_{12}$ : found in liver, meat, eggs, cheese and milk)

11. Vitamin D (found in mackerel and all oily fish, produced in the skin from the energy of the sun)

The following picture, Figure 8, displays how foods, especially the plant power [9] that could help in providing the body with antioxidants referred to above.

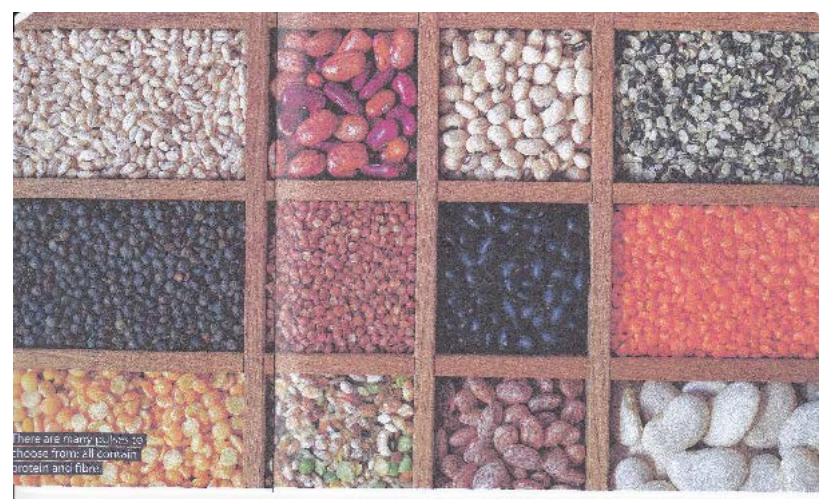

Figure 8. Picture showing various pulses, soya beans, nuts and seeds

Note: Our future paper will pinpoint the types of antioxidant foods that will be suitable for medicinal use against a particular ailment. Further research is underway

\section{Conclusion}

Oxygen is thus essential for our living. However, under certain conditions, this element reacts adversely within the body and transforms into oxygen free radicals, thus attacking body's cells, tissues, organ and eventually affecting our body system [10]. This shows up as a symptom of "disease". Unchecked, this degradation process will result in death and demise of human life.

Concluding note: Human body cannot be maintained and protected against the detrimental force of nature beyond the point of ultimate "human living boundary", which so far has turned out to be of the order of 117 years [11]. Of course, science and technology could work incessantly to shift this boundary to a higher scale.

\section{References}

[1] Google search web site: Oxygen/carbon dioxide recycle: Natural Science \#2: Level 2: Intermediate, $3^{\text {rd }} \& 4^{\text {th }}$ Grade. Available: https://arts2science.wordpress.com/livingthings/plants/photosynth esis/oxygen. [Accessed Jan.13, 2018]

[2] Google search web site: Number of cells in the human body. Available: https://www.google.co.uk [Accessed Jan. 13, 2018]

[3] Google search web site: A candle burning. Explore Green Candle, Rainbow Bridge, \& more. Available: https://www.terest.com/pin/139470919686 14157/ [Accessed Jan.13, 2018]

[4] Carper, J., Food - your miracle medicine, Harper Collins Publishers Inc., New York, 1993, 7-12. 
[5] Google search web site: A chimney emitting smoke. Available: https://www.you tube/watch/picture of a chimney emitting smoke [Accessed Jan. 13, 2018].

[6] Google search web site: A cigarette smoking person, CDC study: Almost half of US teens expose to second hand smoke. Posted 11:00 p.m. Jan 11, 2016, by CNN wire. Available: https://www.google.co.uk/search. [Accessed Jan. 13, 2018].

[7] Google search web site: Picture of an electron orbiting the nucleus. Available:

https://www.google.com/site/mrjhatomichistory/neils-bohr. [Accessed Jan. 13, 2018].
[8] Parker, S., The Human Body Book, Dorling Kindersley Publishers, London, 2013, 269.

[9] Brealey, S., Heart Matters - Plant Power, British Heart Foundation, London, Spring issue 2017, 28-29.

[10] Richards, J., Hallinan, C., Eyewitness Collections - Human Body, Dorling Kindersley Publishers, London, 2013, 12-13.

[11] Glenday, C., Oldest living people: Guinness World Record, 2017 Guinness World Records Limited Publishers, 2018, p.69. 